\title{
The Effect of Cesium-Containing Leucite Additions on the Thermal and Mechanical Properties of Two Leucite-Based Porcelains
}

\author{
Stephen T. Rasmussen, Charles I. McLaren, William J. O'Brien \\ School of Dentistry, University of Michigan, Ann Arbor, Michigan 48109
}

Received 2 December 2002; revised 26 September 2003; accepted 3 October 2003

Published online 27 February 2004 in Wiley InterScience (www.interscience.wiley.com). DOI: 10.1002/jbm.b.30008

\begin{abstract}
It has been demonstrated that $\mathrm{a} \mathrm{Cs}_{2} \mathrm{O}$-stabilized leucite porcelain was susceptible to a stress-induced phase transformation, but toughening was not observed. ${ }^{1}$ It was hypothesized that if $\mathrm{Cs}_{2} \mathrm{O}$-stabilized leucite core particles were added to a cesium-free matrix porcelain, selected or designed to enhance the toughening mechanism, toughening would occur. A commercial porcelain (VP) and a synthesized leucite-based porcelain (NP) were the matrix materials. Core particles of $\mathrm{Cs}_{2} \mathrm{O}(0.0-2.0 \mathrm{~mol} \%)$ containing synthetic leucite were mixed with the two cesium-free matrix porcelains and vacuum fired into specimens for testing. The toughness of both types of matrix-based materials was dependent upon cesium content of the added core particles with a maximum toughness reached for those containing $0.75 \mathrm{~mol} \%$ $\mathrm{Cs}_{2} \mathrm{O}$. The toughness of the $0.75 \mathrm{~mol} \%$ specimens $\left(1.42 \mathrm{MNm}^{-3 / 2}\right.$ for VP based and 2.15 $\mathrm{MNm}^{-3 / 2}$ for NP based) was statistically $(p<.02)$ higher than either of the matrix materials alone or the matrix materials containing added core particles of synthetic cesium-free leucite. However, the toughest materials $\left(0.75 \mathrm{~mol} \% \mathrm{Cs}_{2} \mathrm{O}\right)$ were not the strongest materials, most likely because of large internal flaws. The results suggested that transformation toughening was possible. () 2004 Wiley Periodicals, Inc. J Biomed Mater Res Part B: Appl Biomater 69B: 195-204, 2004
\end{abstract}

Keywords: transformation toughening; strength; thermal expansion; leucite porcelain; cesium

\section{INTRODUCTION}

Based upon clinical and laboratory studies, it has been ${ }^{2}$ proposed that core porcelains for posterior all-ceramic crowns should have flexural strengths of around $400 \mathrm{MPa}$ or better. Two recently developed alumina-based materials ${ }^{3,4}$ have biaxial flexural strengths close to (352 MPa) and exceeding (687 MPa) this value of $400 \mathrm{MPa}$, and these materials had high toughnesses around $4.5 \mathrm{MNm}^{-2 / 3}$. Based upon their properties, these new materials may demonstrate longterm clinical success. However, they have very low translucency ${ }^{3}$ and require expensive equipment and extensive laboratory time compared to traditional dental porcelains, which is considered to be detrimental ${ }^{5}$ to widespread use. At this time, development of a translucent, high-strength material that has a laboratory cost-time basis similar to traditional dental porcelains is a goal not yet achieved by dental materials research.

Correspondence to: William J. O'Brien, Department of Biologic and Materials Science, School of Dentistry, University of Michigan, 1011 N. University Ave., Room 3211, Ann Arbor, MI 48109

Contract grant sponsor: National Institute of Dental Research, National Institutes of Health; contract grant numbers: NRSA F33 DE05636, DE09296-06

(C) 2004 Wiley Periodicals, Inc.
Unfortunately, traditional leucite-based dental porcelains are brittle, and a number of methods have been employed to strengthen restorations made from them. ${ }^{6-8}$ Although leucitebased dental ceramics have not demonstrated a sufficiently high clinical success rate to be used for all ceramic posterior crowns, there is evidence that improvements can be made.

Some ${ }^{9}$ low (tetragonal) leucite-containing glasses (not dental porcelains) had strengths in the 200-300-MPa range, which is much higher than strengths (55-134 MPa) ${ }^{4,10}$ of leucite-based dental porcelains. Research has shown that high (cubic) leucite can be stabilized in dental-porcelain-type compositions at room temperature by the addition of $2 \mathrm{~mol} \% \mathrm{Cs}_{2} \mathrm{O} .{ }^{11}$ Cesium has also been used to control the thermal expansion of a leucite porcelain and, with the right amount of cesium, this material was susceptible to a stress-induced phase transformation (cubic to tetragonal), which introduced the possibility of transformation toughening. ${ }^{1}$ However, it was found that the toughness of their material decreased with increasing content of cesium, consistent with the decreased strength measurements found ${ }^{12}$ for a stabilized cubic leucite porcelain. Another investigation found that toughening occurred if cesium-stabilized leucite was added to an unstabilized commercial porcelain, but strengths were not improved. ${ }^{13}$ The literature suggests that the potential of leucite porcelains has not been fully realized. 
When the primary component of traditional dental porcelain (potash feldspar, $\mathrm{K}_{2} \mathrm{O} \cdot \mathrm{Al}_{2} \mathrm{O}_{3} \cdot 6 \mathrm{SiO}_{2}$ ) is heated above $1150{ }^{\circ} \mathrm{C}$, it changes to leucite $\left(\mathrm{K}_{2} \mathrm{O} \cdot \mathrm{Al}_{2} \mathrm{O}_{3} \cdot 4 \mathrm{SiO}_{2}\right)$ and a liquid rich in $\mathrm{SiO}_{2} \cdot{ }^{14}$ Upon cooling under practical conditions it forms a composite consisting of a core phase of leucite crystals dispersed within a glassy matrix. Leucite has two polymorphs. At high temperatures the stable form of leucite is cubic (high leucite), and as it cools within a glass matrix there is a displacement phase transformation to tetragonal (low leucite) at $605{ }^{\circ} \mathrm{C} .{ }^{15}$ For dental porcelains this transformation occurs in the range of $400-600{ }^{\circ} \mathrm{C} .{ }^{11,16-18}$

According to theory, the strength of leucite dental porcelains could be increased by increasing the volume fraction of the leucite crystals, adding a new dispersed phase, or by reducing the particle size of the dispersed phase. ${ }^{19}$ This theory helps explain how higher strengths $(131 \mathrm{MPa})$ were obtained for an alumina-dispersed ceramic ${ }^{20}$ as compared to regular porcelain and, possibly, why adding zirconia ${ }^{21}$ to a dental porcelain increased its strength. Similarly, commercial feldspathic-based porcelains with a higher weight fraction ${ }^{22}$ of leucite have higher strengths than those ${ }^{10}$ with lower contents of leucite. However, the results were not as clear cut when natural low leucite powders were added to various glasses where flexural strengths decreased, remained unchanged, or increased depending on the type of glass. ${ }^{23-25}$ This discrepancy from theory for leucite additions may be due to the large coefficients of thermal expansion (CTE) mismatch between the glass phase and the dispersed leucite particles. ${ }^{17,23,26}$ The mismatch (due, in part, to the $1.2 \%$ volume contraction of leucite with the cubic to tetragonal transformation that occurs during cooling) can result in stress conditions that deflect propagating cracks around the leucite particles and make the glass matrix the strength-controlling phase. ${ }^{25-, 27}$ Additionally, this mismatch can result in large inherent cracks within the porcelain reducing the material's strength. ${ }^{24,28,29}$ Cesium-stabilized leucite can retain its cubic structure within a glass phase down to room temperature avoiding the cubic to tetragonal transformation. ${ }^{1}$ Potentially, cesium-stabilized leucite could be added to leucite porcelains to increase crystalline content without increasing flaw size and frequency.

High leucite could potentially toughen leucite-glass systems by mechanisms similar to those proposed for zirconia toughening of ceramic systems. That is: (a) crack nucleation/ growth, (b) crack deflection, and (c) stress-induced phase transformation. ${ }^{30}$ Zirconia has been added to a leucite-based porcelain so as to potentially obtain a transformation toughened porcelain. ${ }^{21}$ Although significant improvements in strength and toughness were obtained, the strengths were less than those recommended ${ }^{31}$ for anterior crowns. It should be noted that, in contrast to zirconia, which expands on transformation, high leucite contracts..$^{17,21,26}$

It has been hypothesized ${ }^{1}$ that with appropriate conditions, toughening of cesium-stabilized leucite porcelains could occur when a propagating crack intersected a cesium-stabilized high-leucite particle, transforming it to low leucite with a subsequent volume contraction. If the coefficient of thermal expansion (CTE) of the matrix was the same as or less than that of the high leucite, the matrix would resist the change and therefore be placed in increased compressive hoop stress. The particle would be placed under tension and would crack, but further growth of the crack into the matrix would be inhibited by compressive hoop stresses in the matrix. These increased hoop stresses in the matrix at the crack tip would resist crack growth, thereby toughening the material.

The purpose of this investigation was to determine if a $\mathrm{Cs}_{2} \mathrm{O}$-stabilized leucite porcelain could be made susceptible to transformation toughening. It was proposed that, if cesium was added only to a synthetic leucite to form a transformation-resistant leucite that would be added as a dispersed core phase to a specifically selected or designed leucite-based porcelain matrix (Figure 1), then this new porcelain would be susceptible to transformation toughening. Based on previous research by this laboratory, ${ }^{1}$ it was expected that the potential toughening phenomena would be dependent upon the cesium content of the core particles. That is, the embedded leucite core particles should have enough cesium to retain their cubic structure at room temperature, but not enough to prevent transformation to their tetragonal form when intersected by a stress-driven crack. A matrix material with a CTE close to that of the added core particles was expected to reduce stress fields that could deflect cracks away from the high leucite particles, as happens for typical glass-leucite porcelains. ${ }^{25,27}$

\section{MATERIALS AND METHODS}

\section{Synthetic Materials}

Synthetic leucite $\left(\mathrm{K}_{2} \mathrm{O} \cdot \mathrm{Al}_{2} \mathrm{O}_{3} \cdot 4 \mathrm{SiO}_{2}\right)$ was produced by air firing (Model 46100, high-temperature furnace, Barnstead/Thermolyne, Dubuque, IA) components $\left(\mathrm{K}_{2} \mathrm{O}, \mathrm{Al}_{2} \mathrm{O}_{3}\right.$, $\mathrm{SiO}_{2}$ ) in molar proportions of $1: 1: 4$ at $1600{ }^{\circ} \mathrm{C}$ for $16 \mathrm{~h}$, furnace cooling to $600-700{ }^{\circ} \mathrm{C}$, quenching, and grinding to a powder (diameter $\leq 70 \mu \mathrm{m}$ ) with the use of a motor-driven mortar and pestle (Model 155, Fisher Mortar Grinder, Fisher Scientific Co., Pittsburgh, PA). This process was repeated two more times. Some of this final powder was air fired $(2 \mathrm{~h}$ at $1500{ }^{\circ} \mathrm{C}$, furnace cooled) into solid specimens for thermalexpansion measurements. The synthetic leucite powder was also subjected to quantitative X-ray analysis ${ }^{1,22,32}$ to determine the weight fraction of leucite present with the use of the following formula: ${ }^{1}$

$$
\text { weight fraction(leucite })=\frac{\text { area }(\text { leucite })}{1.73 \times \text { area }(\text { copper })}
$$

Areas $\left(\mathrm{mm}^{2}\right)$ under the X-ray diffraction curves for the low-leucite peak $(d=0.327 \mathrm{~nm})$ and the copper peak $(d=$ $0.209 \mathrm{~nm})$ were used $(\mathrm{CuK} \alpha \mathrm{X}$-ray diffractometer Model XRG-3000, Philips Electronic Instruments, Mahwah, NJ).

$\mathrm{Cs}_{2} \mathrm{O}$ at various $\mathrm{mol} \%(0.0,0.25,0.5,0.75,1.0,1.25,1.50$, $1.75,2.0$, and $4.0 \mathrm{~mol} \%$ ) along with $\mathrm{Al}_{2} \mathrm{O}_{3}$ and $\mathrm{SiO}_{2}$ (molar proportions of $1: 1: 4$ so as to retain stoichiometry of the 


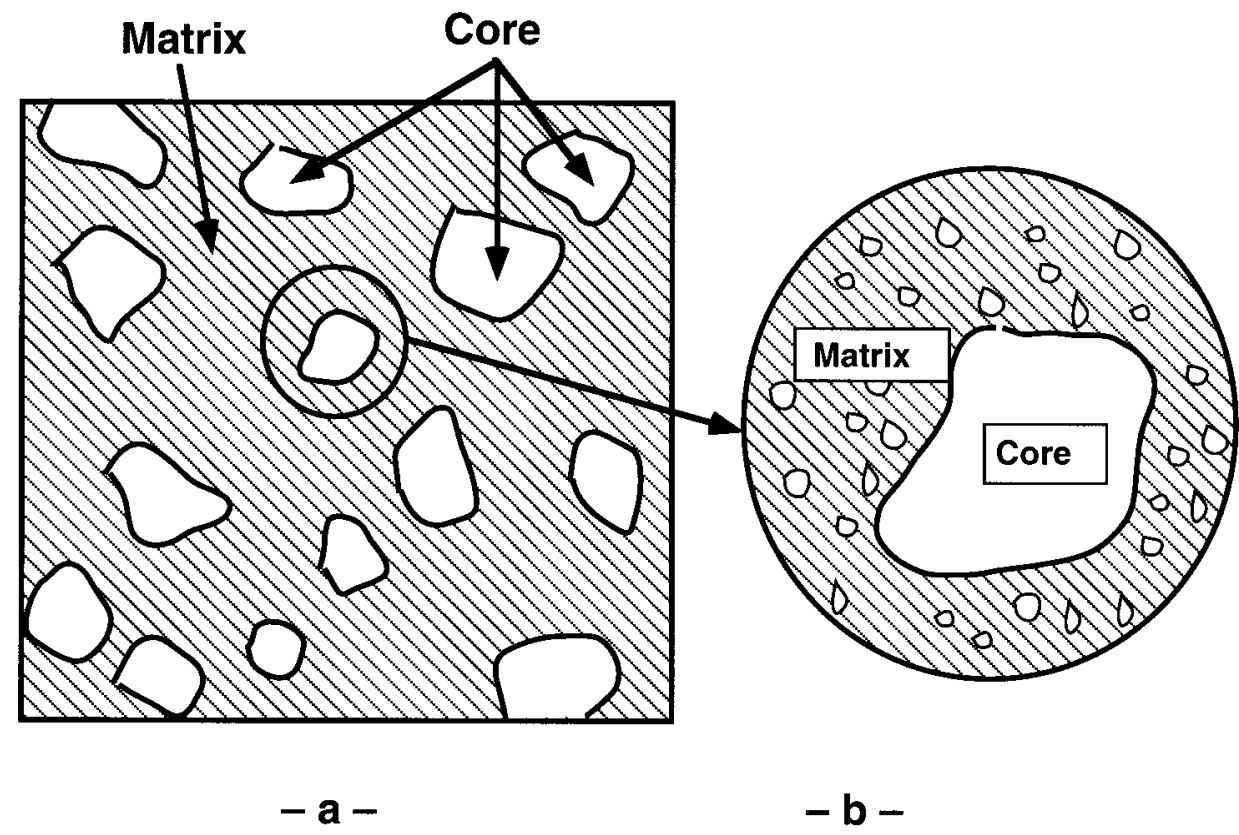

Figure 1. Line drawings of (a) a section through a core-matrix composite and (b) a blowup of a single core particle embedded in a matrix where the matrix is also a core-matrix composite consisting of much smaller core particles as depicted. In this investigation the smallest core particles depicted in (b) may not have had the same composition or structure as the larger core particles that were synthesized.

leucite) were added to the synthetic leucite, air fired at 1550 ${ }^{\circ} \mathrm{C}$ for $14 \mathrm{~h}$ (including $0.0 \mathrm{~mol} \%$ ), furnace cooled to $600-700$ ${ }^{\circ} \mathrm{C}$, quenched, and ground to a powder size dependent on usage. The powders containing $0.0-2.0 \mathrm{~mol} \% \mathrm{Cs}_{2} \mathrm{O}$ were used as the core particles, which were added to the matrix materials. All leucite powders added as a dispersed phase to the matrix porcelains had the same thermal history. Two particle size distributions were produced for use as the added dispersed phase. One had a particle size distribution $\leq 40 \mu \mathrm{m}$ and the other $\leq 15 \mu \mathrm{m}$. The smallest particles were removed from both distributions by sedimentation methods.

Some preliminary X-ray studies were performed on $\mathrm{Cs}_{2} \mathrm{O}$ containing leucite $(2.0-4.0 \mathrm{~mol} \%)$ to determine which formulation would retain cubic structure at room temperature. All powders containing less than $4.0 \mathrm{~mol} \% \mathrm{Cs}_{2} \mathrm{O}$ showed considerable amounts of low leucite at room temperature. Consequently, the $4.0 \mathrm{~mol} \% \mathrm{Cs}_{2} \mathrm{O}$ leucite was chosen as the material with which to determine the CTE of cesium-stabilized cubic leucite. This material's CTE was used to select or to design the two matrix porcelains. The $4.0 \mathrm{~mol} \%$ powder (diameter $\leq 40 \mu \mathrm{m}$ ) was subjected to qualitative X-ray analysis, and some was air fired $\left(2 \mathrm{~h}\right.$ at $\left.1500{ }^{\circ} \mathrm{C}\right)$ into solid specimens for thermal expansion measurements.

A synthetic sodium modified silica-leucite porcelain (NP) powder was prepared from components $\left(\mathrm{K}_{2} \mathrm{O}, \mathrm{Na}_{2} \mathrm{O}, \mathrm{Al}_{2} \mathrm{O}_{3}\right.$, $\mathrm{SiO}_{2}$ ) that were air fired at $1650{ }^{\circ} \mathrm{C}$ for $12 \mathrm{~h}$, furnace cooled to $600-700{ }^{\circ} \mathrm{C}$, quenched, and ground to a powder. The material was ground to a powder $(\leq 70 \mu \mathrm{m})$, which became the NP matrix porcelain. The material was formulated to have a CTE close to that of the 4-mol\% $\mathrm{Cs}_{2} \mathrm{O}$-stabilized high leucite.

\section{Porcelain Specimens}

Two basic types of porcelains were made consisting of two different glass-leucite-based "matrix porcelains" to which were added core particles of synthetic leucite or synthetic cesium-containing leucite. The matrix and core powders were mixed together for $10 \mathrm{~min}$ with the use of a mortar and pestle. The goal was to have the size of the added leucite core particles be much larger than the leucite particles in the matrix porcelain, as depicted in Figure 1(b). The two basic types of porcelain specimens were vacuum fired (Cera-Mat III, Jelrus Dental Products Corp., Hicksville, NY) at experimentally determined firing schedules. The firing schedules included an air quench, which was an automatic feature of the furnace used. The two basic types of porcelains had different firing schedules. The two firing schedules were chosen because specimens subjected to repeat firings exhibited no further shrinkage and produced specimens with minimal isolated porosity, as observed with a light microscope.

The first type of material made consisted of 75 wt.\% matrix of a modified commercial porcelain plus $25 \mathrm{wt} . \%$ core particles of synthetic leucite containing $0.00,0.25,0.50,0.75$, $1.00,1.25,1.50,1.75$, and $2.00 \mathrm{~mol} \% \mathrm{Cs}_{2} \mathrm{O}$ mixed (10 min). The matrix powder was prepared from Vita porcelain (VMK $68 \mathrm{~N}$ Body, H. Rauter GmbH \& Co. KG, Germany) by (a) grinding the original powder to $\leq 15 \mu \mathrm{m}$, (b) vacuum firing for $20 \mathrm{~min}$ at $960{ }^{\circ} \mathrm{C}$, and (c) grinding to powder $\leq 40 \mu \mathrm{m}$. This process was aimed at producing a leucite particle size of $\leq 15 \mu \mathrm{m}$ within the glass matrix, which was much smaller than the particle size of the added synthetic leucite that had been ground to a particle size $\leq 40 \mu \mathrm{m}$. This modified com- 
mercial material was the matrix material to which the synthetic leucite was added. Eleven specimen groups consisting of as-received Vita (VP), matrix Vita [VP(m)], and nine experimental porcelains containing $\mathrm{VP}(\mathrm{m})$ plus added synthetic leucite core particles $[\mathrm{VP}(0.0), \operatorname{VP}(0.25), \mathrm{VP}(0.5)$, $\mathrm{VP}(0.75), \mathrm{VP}(1.0), \mathrm{VP}(1.25), \mathrm{VP}(1.5), \mathrm{VP}(1.75), \mathrm{VP}(2.0)]$ were vacuum fired for $20 \mathrm{~min}$ at $960{ }^{\circ} \mathrm{C}$. The Vita (VP) as-received material was fired at the manufacturer's recommend firing schedule. The specimens were tested for fracture toughness $\left(\mathrm{K}_{\mathrm{IC}}\right)$, Vicker's hardness $(\mathrm{VHN})$, and modulus of rupture (MOR).

As mentioned, theory ${ }^{19}$ suggested that reducing the particle size of the added stabilized leucite particles would improve the toughness and strength of the material to which the particles were added. To this end, a second basic type of porcelain was made, consisting of the NP matrix material (82 wt.\%) to which were added core particles (18 wt.\%, powder diameter $\leq 15 \mu \mathrm{m}$ ) of synthetic leucite containing $0.00,0.25$, $0.50,0.75$, and $1.00 \mathrm{~mol} \% \mathrm{Cs}_{2} \mathrm{O}$. Six specimen groups consisting of NP matrix $[\mathrm{NP}(\mathrm{m})]$ and five stabilized leucite plus $\mathrm{NP}$ matrix porcelains $[\mathrm{NP}(0.0), \mathrm{NP}(0.25), \mathrm{NP}(0.5), \mathrm{NP}(0.75)$, and $\mathrm{NP}(1.0)$ ] were vacuum fired for $20 \mathrm{~min}$ at $1100{ }^{\circ} \mathrm{C}$. These specimens were tested for fracture toughness $\left(\mathrm{K}_{\mathrm{IC}}\right)$, Vicker's hardness (VHN), and modulus of rupture (MOR).

\section{Mechanical and Physical Properties}

Toughness was measured with the use of an indentation method, where a hardness indentation (Vicker's indentation, Tukon Microhardness Tester, Wilson Instruments, Division of Instron Corp., Bridgeport, CT) was made in the surface of the specimen, producing cracks of length $\mathrm{C}(\mathrm{m})$ measured from the center of the indentation to the tip of the crack. The following formula ${ }^{33}$ was used to determine the $\mathrm{K}_{\mathrm{IC}}$ of the material:

$$
\mathrm{K}_{\mathrm{IC}}=0.016 \frac{P}{C^{3 / 2}}\left(\frac{E}{H}\right)^{1 / 2},
$$

where $P$ (Newtons) is the load to make the indentation, $E$ the material's elastic modulus, and $H$ its hardness (GPa). The $E$ of leucite-based dental porcelains ranges from $60-70 \mathrm{GPa}$ and the $E$ of the commercial porcelain used here (Vita) was reported $^{34}$ to be $69 \mathrm{GPa}$. An $E$ of $69 \mathrm{GPa}$ was used for all toughness calculations. The load $P(2 \mathrm{~kg}, 19.614 \mathrm{~N})$ was chosen after preliminary tests indicated that the indentation dimensions would be larger than those of the added leucite particles. Higher loads cracked some of the specimens.

The modulus of rupture strength (MOR) was measured under three-point loading. The specimens were tested with a universal testing instrument (Model TTBM, Instron Corp., Canton, MA) at a cross-head speed of $0.05 \mathrm{~cm} / \mathrm{min}$.

MOR specimens were finished with optical flat grinding techniques so that they had parallel surfaces (accurate to $\pm 0.03^{\circ}$ ) with the use of 320 -grit $\mathrm{SiC}$ powder on a glass plate. Tested MOR specimen halves were finished sequentially (320-, 400-, and 600-grit $\mathrm{SiC}$ paper) to a final finish by 6- $\mu \mathrm{m}$ diamond compound ( DC-122, Mager Scientific Inc., Dexter, MI) for toughness testing.

Six specimens of low leucite, stabilized leucite $(4.0 \mathrm{~mol} \%$ $\mathrm{Cs}_{2} \mathrm{O}$ ), and NP matrix were tested for linear thermal expansion behavior at constant rates $\left(3^{\circ} \mathrm{C} / \mathrm{min}\right)$ of heating with the use of a dilatometer $\left(1200{ }^{\circ} \mathrm{C}\right.$ Vertical Dilatometer, Theta Industries, Port Washington, NY) calibrated with a platinum standard. The coefficients of thermal expansion $(\alpha)$ from room temperature to various temperatures were determined during the heating cycle.

Particle size measurements were made with the use of a stereo microscope with a measuring reticule (STEMI SV8, Zeiss, Oberkochen, Germany) for particle diameters larger than $15 \mu \mathrm{m}$ and a microscope with a filar eyepiece (Tukon, Wilson, Bridgeport, CT) for smaller particle sizes.

\section{Scanning Electron Microscopy (SEM)}

Specimens that had been finished as above with $6-\mu \mathrm{m}$ diamond were examined for porosity, and some were etched 6-12 s with hydrofluoric acid etching gel (Ceramic Etchant, Ceramco, Burlington, NJ) or $1 \%$ hydrofluoric acid. These specimens were examined with a light microscope and SEM (normal SEM and with a solid-state back-scatter electron detector, model S-3200N, Hitachi, Tokyo, Japan). Additionally, fractured surfaces were viewed with a light microscope and SEM. In hopes of distinguishing the cesium-containing leucite core particles from matrix leucite, the polished NPbased porcelains were carbon coated for detection of backscattered electrons.

\section{Statistics}

Property means and standard deviations (SD) were determined for all specimen groups. Properties of all material groups having the same type of matrix were compared to determine if a significant variance existed between groups with the use of one-way analysis of variance (ANOVA). If a significant variance $(p<.05)$ was found, specimen groups were compared with the use of Fisher's protected leastsignificant differences (PLSD).

\section{RESULTS}

X-ray diffraction patterns [Figure 2(a)] for powdered synthetic nonstabilized leucite showed peaks that corresponded to low (tetragonal) leucite and one peak that was unidentified. Based on principle peak area measurements and Eq. (1), this synthetic material contained $97 \%(\mathrm{SD}= \pm 5 \%)$ low leucite. $\mathrm{X}$-ray diffraction patterns [Figure 2(b)] for powdered synthetic stabilized $\left(4.0 \mathrm{~mol} \% \mathrm{Cs}_{2} \mathrm{O}\right)$ leucite showed peaks that corresponded to high (cubic) leucite, and two peaks were attributed to low leucite. Some of the intensity of the highleucite peaks may have been due to the presence of low leucite. These results showed that synthetic low leucite was produced and that the stabilized material was close in struc- 

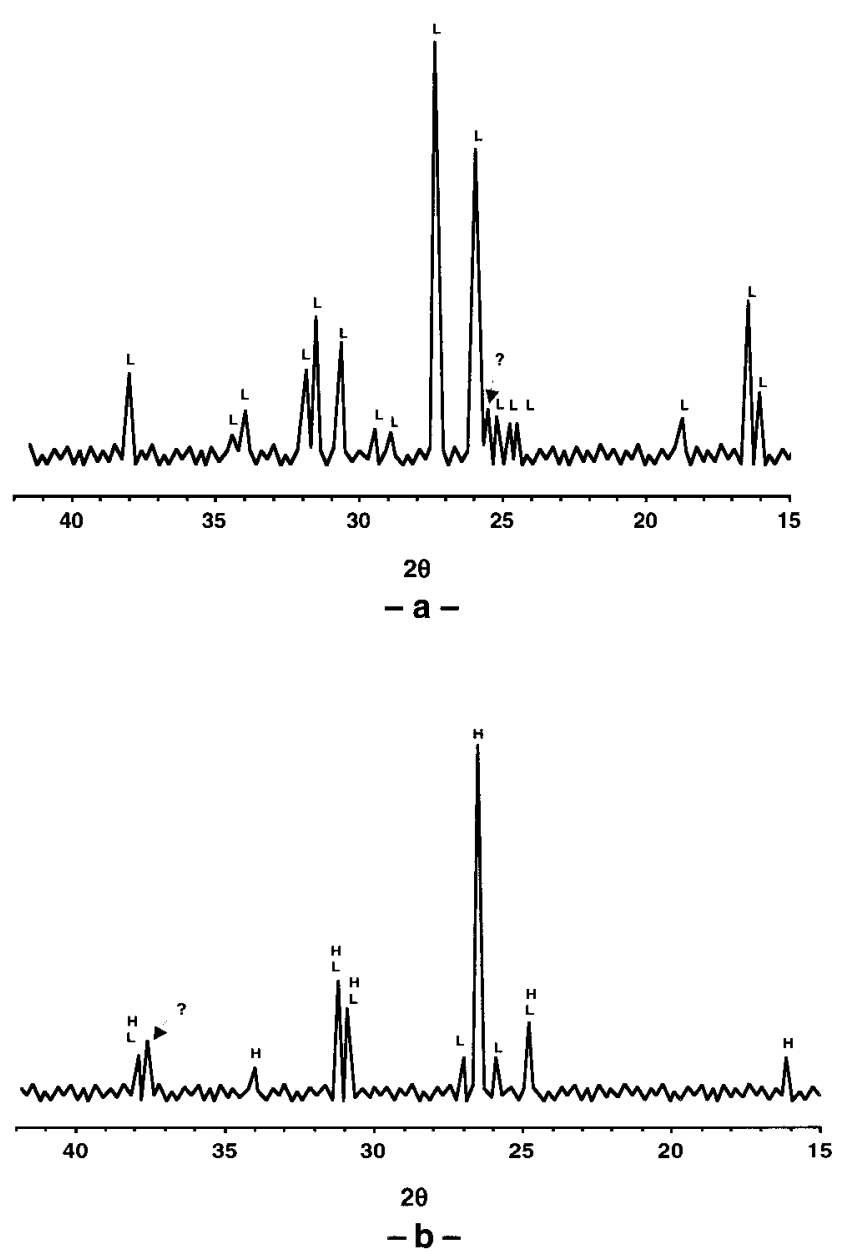

Figure 2. Line drawings depicting X-ray diffraction patterns of a specimen of (a) synthetic low (tetragonal) leucite, where the letter $L$ indicates a low leucite peak and the question mark indicates an unidentified peak; and (b) synthetic high (cubic) leucite containing 4 mol\% $\mathrm{Cs}_{2} \mathrm{O}$ where the letter $\mathrm{H}$ indicates a high-leucite peak. Low leucite was detected in the high-leucite specimen. Some low-leucite peaks were close to those of high leucite, so that some of the intensity of the high-leucite peaks could be attributed to low leucite. Those peaks are indicated by $\mathrm{H}$ and $\mathrm{L}$ together. These figures give relative intensity and the $2 \theta$ spacing of peaks for one specimen of each material depicted.

ture to high leucite with a small amount of low leucite present.

Figure 3 shows the averaged (six specimens/group) thermal expansion curves for the synthetic low and high leucite $\left(4.0 \mathrm{~mol} \% \mathrm{Cs}_{2} \mathrm{O}\right)$ plus that for the NP-matrix porcelain. Table I gives the mean CTE and standard deviation for these three materials over various temperature ranges. Figure 3 shows that the expansion of the synthetic high leucite and the NP-matrix porcelain were similar from $600-700{ }^{\circ} \mathrm{C}$.

The smallest indentation obtained for VP-based materials, which occurred for $\operatorname{VP}(0.5)$ materials, had an area that was approximately (spherical particles are assumed) 1.5 times the area of the largest core particles added. The smallest indentation obtained for NP-based materials, which occurred for $\mathrm{NP}(0.75)$ materials, had an area that was 14 times the area of the largest core particles added.

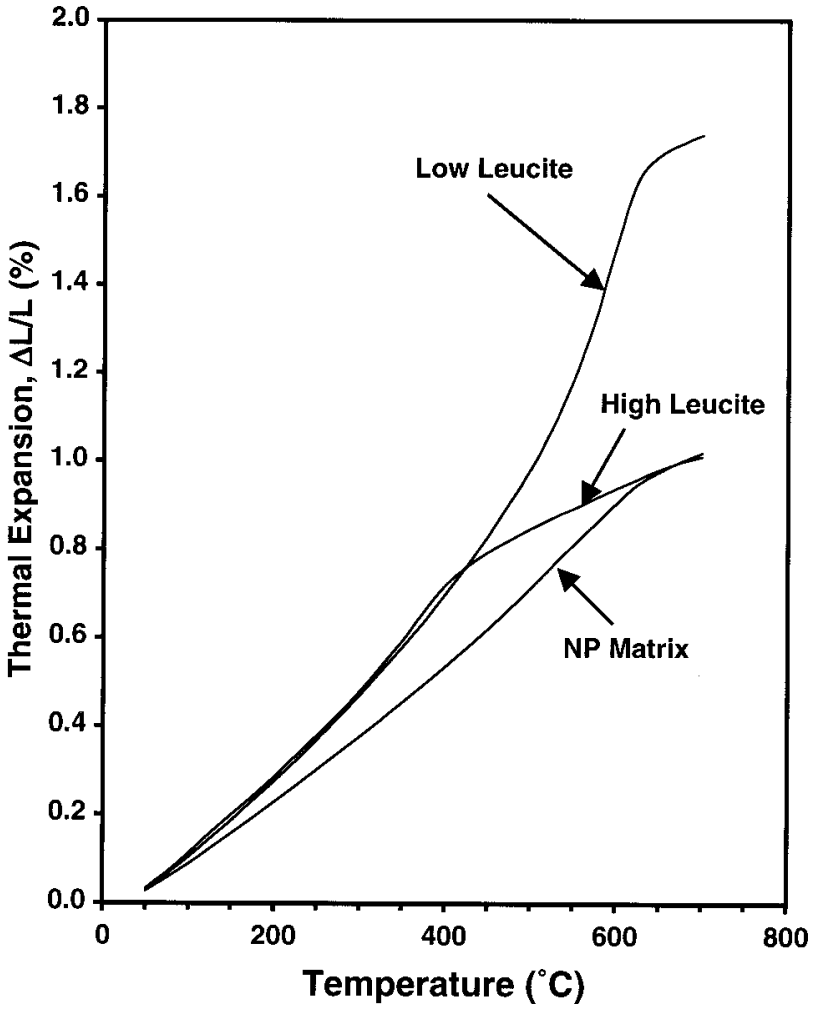

Figure 3. Line drawings of the thermal expansions for the synthesized materials low leucite, high leucite $\left(4 \mathrm{~mol}_{\mathrm{C}} \mathrm{Cs}_{2} \mathrm{O}\right)$, and the NP porcelain that was used as a matrix material. Each line represents an average over six specimens.

Table II gives hardness $(\mathrm{VHN})$ and toughness $\left(\mathrm{K}_{\mathrm{IC}}\right)$ for the porcelains derived from the commercial porcelain (VP). ANOVA revealed a significant variance $(p<.0001)$ between specimen groups for both types of measurements. Figure 4 shows the functional dependence of $\mathrm{K}_{\mathrm{IC}}$ on $\mathrm{Cs}_{2} \mathrm{O}$ content and shows that a maximum in $\mathrm{K}_{\mathrm{IC}}$ was reached around 0.75 $\mathrm{mol} \% . \mathrm{K}_{\mathrm{IC}}$ of $\mathrm{VP}(0.75)$ was significantly higher than the as-received commercial material (VP, $p<.0001)$, the matrix

TABLE I. Mean Coefficients of Thermal Expansion $(\alpha)$ for Low (Tetragonal), High (Cubic) Leucite and NLP Matrix

\begin{tabular}{cccc}
\hline \multirow{2}{*}{$\begin{array}{c}\text { Temperature } \\
\text { Range }\left({ }^{\circ} \mathrm{C}\right)\end{array}$} & Low Leucite & High Leucite & NLP Matrix \\
\cline { 2 - 4 } & $15.1 \pm 2.6$ & $16.9 \pm 0.6$ & $12.9 \pm 0.1$ \\
$25-150$ & $15.9 \pm 2.1$ & $16.9 \pm 0.5$ & $13.3 \pm 0.1$ \\
$25-200$ & $16.5 \pm 1.7$ & $17.4 \pm 0.4$ & $13.6 \pm 0.1$ \\
$25-250$ & $17.2 \pm 1.4$ & $17.9 \pm 0.4$ & $13.8 \pm 0.1$ \\
$25-300$ & $17.9 \pm 1.2$ & $18.7 \pm 0.4$ & $14.1 \pm 0.1$ \\
$25-350$ & $18.7 \pm 1.1$ & $19.5 \pm 0.4$ & $14.4 \pm 0.1$ \\
$25-400$ & $19.6 \pm 0.9$ & $19.0 \pm 0.3$ & $14.7 \pm 0.1$ \\
$25-450$ & $20.8 \pm 0.8$ & $18.1 \pm 0.3$ & $15.1 \pm 0.1$ \\
$25-500$ & $22.6 \pm 0.8$ & $17.2 \pm 0.4$ & $15.5 \pm 0.1$ \\
$25-550$ & $26.0 \pm 0.9$ & $16.5 \pm 0.4$ & $15.8 \pm 0.1$ \\
$25-600$ & $27.2 \pm 0.9$ & $15.9 \pm 0.4$ & $15.7 \pm 0.1$ \\
$25-650$ & $25.9 \pm 0.9$ & $15.1 \pm 0.4$ & $15.2 \pm 0.1$ \\
$25-700$ & &
\end{tabular}


TABLE II. Fracture Toughness $\left(K_{1 C}\right)$ and Vickers Hardness Number (VHN) for Porcelains Consisting of a Matrix Material [V(m)] Made from a Commercial Porcelain (V) to Which Was Added Core Powders of a Synthetic Leucite Containing 0.0-2.0 mol \% of Cesium Oxide

\begin{tabular}{lcll}
\hline Group & Count & $\begin{array}{c}\text { VHN }(\mathrm{GPa}) \\
\text { Mean } \pm \mathrm{SD}^{\mathrm{a}, \mathrm{b}, \mathrm{c}}\end{array}$ & $\begin{array}{c}\mathrm{K}_{\mathrm{IC}}\left(\mathrm{MPa} \cdot \mathrm{m}^{1 /}\right. \\
2) \text { Mean } \pm \mathrm{SD}^{\mathrm{d}}\end{array}$ \\
\hline $\mathrm{V}$ & 10 & $7.16 \pm 0.46^{\mathrm{a}, \mathrm{b}, \mathrm{c}}$ & $0.85 \pm 0.11$ \\
$\mathrm{~V}(\mathrm{~m})$ & 10 & $7.46 \pm 0.21^{\mathrm{c}}$ & $0.87 \pm 0.05$ \\
$\mathrm{~V}(1.25)$ & 10 & $7.07 \pm 0.46^{\mathrm{a}, \mathrm{b}, \mathrm{c}}$ & $1.11 \pm 0.28$ \\
$\mathrm{~V}(0.5)$ & 10 & $8.12 \pm 0.76$ & $1.14 \pm 0.14$ \\
$\mathrm{~V}(0.0)$ & 10 & $7.27 \pm 0.32^{\mathrm{b}, \mathrm{c}}$ & $1.21 \pm 0.13$ \\
$\mathrm{~V}(0.25)$ & 10 & $7.33 \pm 0.43^{\mathrm{c}}$ & $1.22 \pm 0.17$ \\
$\mathrm{~V}(1.75)$ & 10 & $6.84 \pm 0.70^{\mathrm{a}, \mathrm{b}}$ & $1.26 \pm 0.20$ \\
$\mathrm{~V}(1.5)$ & 10 & $7.02 \pm 0.52^{\mathrm{a}, \mathrm{b}, \mathrm{c}}$ & $1.27 \pm 0.21$ \\
$\mathrm{~V}(2.0)$ & 10 & $7.06 \pm 0.60^{\mathrm{a}, \mathrm{b}, \mathrm{c}}$ & $1.28 \pm 0.12$ \\
$\mathrm{~V}(1.0)$ & 10 & $6.72 \pm 0.65^{\mathrm{a}}$ & $1.31 \pm 0.18$ \\
$\mathrm{~V}(0.75)$ & 10 & $5.87 \pm 0.42$ & $1.42 \pm 0.21$ \\
\hline
\end{tabular}

a,b,c $l l$ groups having the same letter had statistically similar $(p>.05)$ mean hardness.

${ }^{\mathrm{d}} 11$ groups connected by a line had statistically similar $(p>.05)$ mean toughness.

material $[\mathrm{VP}(\mathrm{m}), p<.0001]$ and the matrix material with $25 \%$ synthetic leucite added [VP(0.0), $p=.0083]$.

Table III gives MOR for the porcelains derived from the commercial porcelain (VP). ANOVA revealed a significant variance $(p=.0001)$ between specimen groups for MOR measurements. Despite having the highest toughness, VP(0.75) had the lowest MOR.

Table IV gives hardness (VHN) and toughness $\left(\mathrm{K}_{\mathrm{IC}}\right)$ for the porcelains derived from the synthetic NP porcelain. ANOVA revealed a significant variance $(p<.0001)$ between specimen groups for $\mathrm{K}_{\mathrm{IC}}$ but not for $\operatorname{VHN}(p=.25)$. Figure

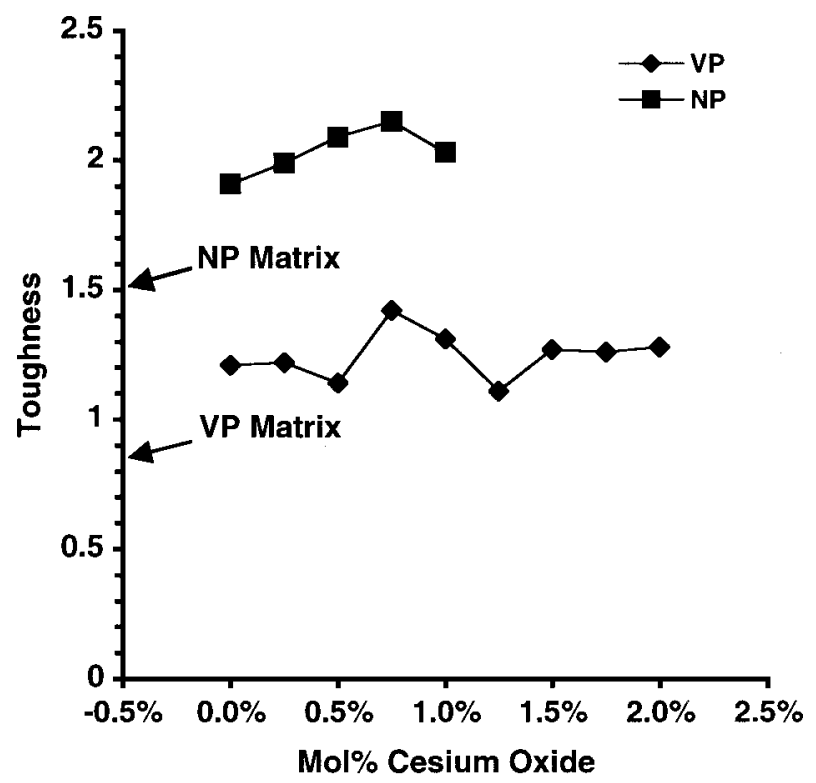

Figure 4. Average toughness $\left(\mathrm{MNm}^{-3 / 2}\right)$ versus $\mathrm{mol} \% \mathrm{Cs}_{2} \mathrm{O}$ is plotted for VP- and NP-based porcelains. The toughnesses of the two matrix materials are also indicated by the arrows at the $Y$ axis.
TABLE III. Modulus of Rupture (MOR) for Porcelains Consisting of a Matrix Material [V(m)] Made from a Commercial Porcelain (V) to Which was Added Core Powders of a Synthetic Leucite Containing $\mathbf{0 . 0 - 2 . 0 ~ m o l \% ~ o f ~ C e s i u m ~ O x i d e ~}$

\begin{tabular}{lcc|}
\hline Group & Count & $\begin{array}{c}\text { MOR }(\mathrm{MPa}) \\
\text { Mean } \pm \mathrm{SD}^{\mathrm{a}}\end{array}$ \\
\hline $\mathrm{V}(0.75)$ & 7 & $80.1 \pm 7.9$ \\
$\mathrm{~V}(1.75)$ & 6 & $86.8 \pm 7.9$ \\
$\mathrm{~V}(1.5)$ & 6 & $88.0 \pm 4.1$ \\
$\mathrm{~V}$ & 6 & $89.8 \pm 3.4$ \\
$\mathrm{~V}(1.0)$ & 6 & $91.1 \pm 5.7$ \\
$\mathrm{~V}(0.5)$ & 6 & $92.3 \pm 4.9$ \\
$\mathrm{~V}(1.25)$ & 6 & $93.4 \pm 8.0$ \\
$\mathrm{~V}(0.25)$ & 6 & $94.8 \pm 12.2$ \\
$\mathrm{~V}(2.0)$ & 6 & $98.6 \pm 6.1$ \\
$\mathrm{~V}(\mathrm{~m})$ & 7 & $102.8 \pm 7.8$ \\
$\mathrm{~V}(0.0)$ & 6 & $106.3 \pm 12.5$ \\
\hline
\end{tabular}

${ }^{a} 11$ specimen groups connected by vertical lines were statistically similar $(p>.05)$ with respect to mean MOR.

4 shows the dependence of $\mathrm{K}_{\mathrm{IC}}$ on $\mathrm{Cs}_{2} \mathrm{O}$ content and shows that a maximum in $\mathrm{K}_{\mathrm{IC}}$ was reached around $0.75 \mathrm{~mol} \%$. $\mathrm{K}_{\mathrm{IC}}$ of $\mathrm{NP}(0.75)$ was significantly higher than the NP matrix ( $p<$ $.0001)$ and the matrix material with $18 \%$ synthetic leucite added [NP(0.0), $p=.017]$.

Table $\mathrm{V}$ gives MOR for the porcelains derived from the synthetic NP porcelain. The variance (ANOVA) between specimen groups for MOR was not significant $(p=.16)$. Despite having the highest toughness, the $\mathrm{NP}(0.75)$ specimens did not have the highest MOR.

Although a significant variance was found for the VHN (Table II) and MOR (Table III) of porcelains derived from the commercial porcelain (VP), plots (not shown here) of these two properties as a function of $\mathrm{Cs}_{2} \mathrm{O}$ content revealed no obvious trends dependent upon $\mathrm{Cs}_{2} \mathrm{O}$. A minimum VHN and MOR occurred for $\mathrm{V}(0.75)$ specimens, but this minimum was not found for the NP porcelains.

Polished specimens of all types of porcelains investigated showed minimal amounts of porosity and were basically

TABLE IV. Fracture Toughness $\left(K_{\mathrm{IC}}\right)$ and Vickers Hardness Number (VHN) for Porcelains Consisting of a Synthetic LeuciteGlass Porcelain Matrix Material [N(m)] to Which Was Added Core Powders of a Synthetic Leucite Containing 0.0-1.0 mol\% of Cesium Oxide

\begin{tabular}{lccc}
\hline Group & Count & $\begin{array}{c}\text { VHN }(\mathrm{GPa}) \\
\text { Mean } \pm \mathrm{SD}^{\mathrm{a}}\end{array}$ & $\begin{array}{c}\mathrm{K}_{\mathrm{IC}}\left(\mathrm{MPa} \cdot \mathrm{m}^{1 / 2}\right) \\
\text { Mean } \pm \mathrm{SD}^{\mathrm{b}}\end{array}$ \\
\hline $\mathrm{N}(\mathrm{m})$ & 11 & $4.88 \pm 0.32$ & $1.51 \pm 0.15$ \\
$\mathrm{~N}(0.0)$ & 10 & $4.39 \pm 0.17$ & $1.91 \pm 0.17$ \\
$\mathrm{~N}(0.25)$ & 10 & $4.43 \pm 0.23$ & $1.99 \pm 0.13$ \\
$\mathrm{~N}(1.0)$ & 14 & $4.57 \pm 0.91$ & $2.03 \pm 0.21$ \\
$\mathrm{~N}(0.5)$ & 10 & $4.23 \pm 0.40$ & $2.09 \pm 0.22$ \\
$\mathrm{~N}(0.75)$ & 10 & $4.61 \pm 0.98$ & $2.15 \pm 0.33$ \\
\hline
\end{tabular}

${ }^{a}$ NOVA showed that all specimen groups for hardness had statistically similar ( $p=$ $0.25)$ means.

b 11 specimen groups connected by vertical lines were statistically similar $(p>$ 0.05 ) with respect to mean toughness. 
similar when examined with a light microscope. However, major differences between types of polished-etched NP based specimens were found when they were examined at higher magnifications with a SEM (Figure 5) with back-scattered electrons. Figure 5(b, c) shows regions of the specimens that had the most porosity present. Other regions had considerably less porosity, but the difference was not quantified. The $\mathrm{Cs}_{2} \mathrm{O}$ content $(0.75 \mathrm{~mol} \%)$ of the added stabilized leucite was not sufficient to give contrast differences from normal leucite of the matrix porcelain when viewed with back-scattered electrons [Figure 5(c)].

The VP-based porcelains were not as extensively investigated with SEM. However, at $100 \times$ magnification SEM revealed that the various VP-based porcelains were similar with regard to porosity. Polished-etched specimens had porosity that was roughly spherical in shape [similar in size and shape to that shown in Figure 5(b)], but widely separated from each other so that extensive regions were porosity free.

SEM revealed major differences between three types of NP-based porcelains with regard to cracks (Figure 5). Cracks were intimately associated with the leucite particles.

SEM fractographs confirmed observations regarding porosity, leucite particle size, and cracks. These fractographs also showed that the primary failure mode was within the glass phase, bypassing the leucite particles for the low-leucite-containing NP-matrix material and $\mathrm{NP}(0.0)$ porcelain, consistent $^{12,23,27}$ with other research. In contrast, the $\mathrm{NP}(0.75)$ fractographs were much smoother than the NP and $\mathrm{NP}(0.0)$ porcelains, which indicated that leucite particles were intersected and fractured. However, they did not reveal new information regarding critical flaws. Consequently, these fractographs are not shown here.

\section{DISCUSSION}

The $\mathrm{K}_{\mathrm{IC}}$ data (Tables II and IV) coupled with a previous finding ${ }^{1}$ that a stress-induced phase transformation was possible in a cesium-stabilized commercial porcelain, strongly suggest that leucite-based porcelains can be made susceptible to transformation toughening. The dependence of $\mathrm{K}_{\mathrm{IC}}$ upon

TABLE V. Modulus of Rupture (MOR) for Porcelains Consisting of a Matrix Material Made from a Synthetic Leucite-Glass Porcelain Matrix Material [N(m)] to which Was Added Core Powders of a Synthetic Leucite Containing 0.0-1.0 mol\% of Cesium Oxide

\begin{tabular}{lcc}
\hline Group & Count & $\begin{array}{c}\text { MOR }(\mathrm{MPa}) \\
\text { Mean } \pm \mathrm{SD}^{\mathrm{a}}\end{array}$ \\
\hline $\mathrm{N}(\mathrm{m})$ & 7 & $109 \pm 6$ \\
$\mathrm{~N}(0.75)$ & 6 & $112 \pm 11$ \\
$\mathrm{~N}(0.5)$ & 6 & $120 \pm 12$ \\
$\mathrm{~N}(0.0)$ & 6 & $121 \pm 6$ \\
$\mathrm{~N}(1.0)$ & 6 & $121 \pm 9$ \\
$\mathrm{~N}(0.25)$ & 6 & $121 \pm 14$ \\
\hline
\end{tabular}

${ }^{\mathrm{a} A N O V A}$ showed that group means were statistically similar $(p=0.16)$.
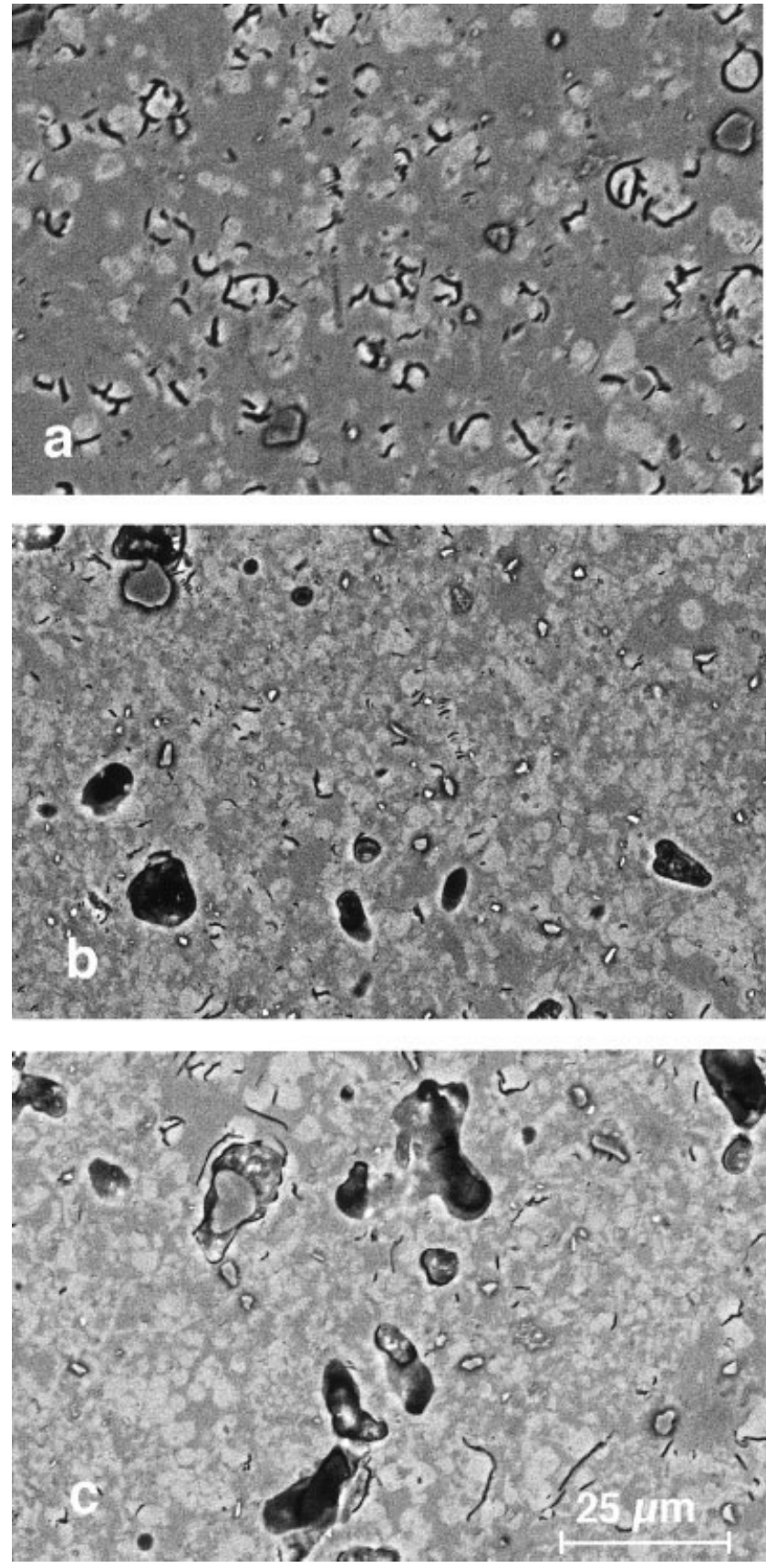

Figure 5. SEM (back-scattered electrons) micrographs of polished and etched surfaces of (a) NP-matrix porcelain, (b) porcelain $[\mathrm{NP}(0.0)]$ consisting of $82 \%$ NP porcelain plus $18 \%$ core particles of synthetic leucite, and (c) porcelain $[\mathrm{NP}(0.75)]$ consisting of $82 \% \mathrm{NP}$ porcelain plus $18 \%$ core particles of $0.75 \mathrm{~mol} \% \mathrm{Cs}_{2} \mathrm{O}$ stabilized leucite. Particles evident in (c) consist of leucite and stabilized leucite. Arrows indicate cracks within the material. (b) and (c) show regions of the specimens, that had the most porosity present. Other regions had considerably less porosity but the difference was not quantified. Compositional differences were not sufficient for the back-scattered electron detector to distinguish between stabilized and nonstabilized leucite particles.

$\mathrm{Cs}_{2} \mathrm{O}$ content for both VP- and NP-based porcelains (Figure 4) indicated that transformation toughening occurred. That is, $\mathrm{K}_{\mathrm{IC}}$ generally increased with $\mathrm{Cs}_{2} \mathrm{O}$ content, reached a maxi- 
mum at $0.75 \mathrm{~mol} \%$, and then decreased with higher content, suggesting that the maximum in $\mathrm{K}_{\mathrm{IC}}$ was not a statistical fluctuation. This shows that the increase in toughness was not due to just the addition of more crystalline phase or for the addition of high leucite, which previous research ${ }^{1}$ indicated would be stable in a glass matrix even after crushing if it contained $\geq 1.5 \mathrm{~mol} \% \mathrm{Cs}_{2} \mathrm{O}$. Additionally, some of the new materials (VP and NP based) had toughnesses considerably higher than those reported ${ }^{3,4}$ for commercially available leucite-based porcelains.

The $\mathrm{K}_{\mathrm{IC}}$ results coupled with previous work $^{1}$ were also consistent with the concept of designing the matrix to enhance the proposed toughening mechanism. When $\mathrm{Cs}_{2} \mathrm{O}$ was added directly to a leucite porcelain, toughening did not occur. ${ }^{1}$ The stabilized high-leucite particles would have been embedded in a glass matrix of considerably lower CTE. The CTE of the glass phase of dental porcelains is low $(8.4 \times$ $\left.10^{-6} /{ }^{\circ} \mathrm{C}\right){ }^{17}$ compared to the CTE of stabilized high leucite (Table I). This mismatch in CTE between matrix and core particles would have led to compressive-hoop stresses and tensile-radial stresses. These stress fields could have increased the probability that a crack would be deflected away from the stabilized high-leucite core particles, thereby negating potential toughening effects. Consequently, the potential for toughening would be reduced in this material. In contrast, the matrix materials used here were designed to reduce the stress fields that arose due to CTE mismatch, thereby increasing the probability that the stabilized-leucite particles would be intersected. Vita was chosen as a matrix material because its CTE $\left(12.7-14.5 \times 10^{\left.-6 /{ }^{\circ} \mathrm{C}\right)}{ }^{35}\right.$ was at the lower range reported $^{26}$ for high leucite $\left(11.7-22.3 \times 10^{-6} /{ }^{\circ} \mathrm{C}\right)$. Coupling the modified Vita $[\mathrm{VP}(\mathrm{m})]$ with stabilized high leucite led to toughening. The NP porcelain was specifically designed to match the CTE of stabilized high leucite (Figure 3 and Table I), and this material achieved the highest toughness. It should be noted that although the NP-based porcelains had less (18 wt.\% vs. 25 wt.\%) stabilized leucite, the added core particles were much smaller $(\leq 15 \mu \mathrm{m}$ vs. $\leq 40 \mu \mathrm{m})$ than for the Vita-based porcelains. Theory ${ }^{19}$ suggests that the higher toughness of the $\mathrm{NP}(0.75)$ compared to the $\mathrm{VP}(0.75)$ may have been due to the smaller added core particles rather than the better matching of the CTE between core particles and matrix for the $\mathrm{NP}(0.75)$ material.

It is important to discuss whether the indentations used for hardness and toughness measurements were large enough to be representative of the material as a whole or gave small regional indications of these properties. The smallest indentation found for the NP-based materials had a diagonal of length $70 \mu \mathrm{m}$. For the NP-based materials the indentations were considerably larger than the microstructure shown in Figure 5, which suggests that the measurements were representative of the material as a whole. The smallest indentation (diagonal $=62 \mu \mathrm{m}$ ) found for the VP-based material occurred for a $\mathrm{VP}(0.5)$ specimen. Although it was more likely that the hardness indentation would have intersected much smaller added core particles, regional variations in hardness measurements could have occurred for the VP-based materi- als. Inspection of the hardness data in Table II suggests that, if there were regional variations due to the size of the indentations, the variations were small. That is, the standard deviations were not large. Because the smallest measured crack length (induced disc-shaped crack of diameter $2 C$ and depth $C$ ) was $156 \mu \mathrm{m}=2 C$, the crack length was probably not a problem for this material for measurement of toughness.

At this point it is not clear why two of the specimen groups [NP(0.75) and NP(1.0)] for the NP-based materials had relatively high standard deviations (cf. Table IV). If it was due to porosity, then those specimens with the lowest hardness should have had high toughness, but they did not. That is, an indenter that intersected large amounts of porosity, giving a large indentation [low VHN, $H$ in Eq. (2)], would induce lower stresses for crack initiation, leading to artificially small crack lengths [ $C$ in Eq. (2)], thereby, give an artificially high number for toughness. For specimen group $\mathrm{NP}(0.75)$ the three toughness measurements having the lowest hardnesses showed a below-average toughness $\left(1.99 \mathrm{MNm}^{-3 / 2}\right.$ vs. group average $\left.2.15 \mathrm{MNm}^{-3 / 2}\right)$ and similarly for specimen group $\mathrm{NP}(1.0)\left(2.01 \mathrm{MNm}^{-3 / 2}\right.$ vs. group average $\left.2.03 \mathrm{MNm}^{-3 / 2}\right)$.

It is likely that the largest inherent flaws for typical leucite porcelains would be those that arise, in some way, because of the CTE mismatch between the glass and leucite phases. These flaws are approximately the size of leucite particles contained in typical leucite porcelains, and are intimately associated with the leucite particles. ${ }^{12,28}$ Larger flaws can arise when agglomeration of leucite particles occurs. ${ }^{29}$ The flaws shown in Figure 5(a) probably occurred because of this CTE mismatch. There were considerably more cracks per unit area than for typical leucite porcelains, which suggests that the CTE mismatch was greater for the NP porcelain. However, a comparison of all the micrographs in Figure 5 suggests that the cause of crack formation is more complex than indicated by the above simple explanation. For example, based on theory, the $\mathrm{NP}(0.0)$ specimens [Figure 5(b)] should have shown a greater frequency of cracks than the matrix material NP [Figure 5(a)] because of greater leucite content, but it did not. It should be noted that etching of the specimens possibly altered the appearance and frequency of cracks, thereby making it difficult to make definite conclusions regarding flaws.

The MOR data did not follow the trends found for those of toughness, as might have been expected. The apparently contradictory results regarding $\mathrm{K}_{\mathrm{IC}}$ and MOR data were consistent with flaws shown in Figure 5 and with the proposed toughening mechanism. When strength does not follow $\mathrm{K}_{\mathrm{IC}}$ increases, larger surface flaws are the likely explanation. These flaws could be induced by finishing procedures, or could be inherent flaws that are exposed by finishing procedures. It was probable that the largest flaws shown in Figure 5 were similar in size to the critical flaws that resulted in failure of these three types of specimens when they were tested for MOR strength. The $\mathrm{NP}(0.75)$ specimens had the largest flaws found, as is evident in Figure 5(c). Despite having a high toughness, the relatively low MOR strength of 
the $\mathrm{NP}(0.75)$ specimens could have been due to these large flaws.

If the proposed toughening mechanism was correct, then larger flaws could have been created by the same process that led to toughening. For example, large flaws could have resulted for the $0.75 \mathrm{~mol} \% \mathrm{Cs}_{2} \mathrm{O}$ specimens of VP- or NP-based porcelains when induced cracks (CTE mismatch or mechanical finishing procedures) were not arrested at a high-leucite particle, but would transform and crack them, and then stop at the particle-matrix boundary. The transformation from high to low leucite would place the particle under tension, which would supply additional strain energy to drive the crack through the particle, thereby increasing the crack length by a particle diameter.

It is important to note that although core particle size and weight percent probably had a significant effect on the properties of the materials studied here, these factors were probably not the source of the major differences found with regard to toughness and $\mathrm{Cs}_{2} \mathrm{O}$ content. Core particle sizes and amounts for each matrix-based porcelain with added leucite were kept similar [cf. Figure 5(b, c)]; however, significant differences in toughness were found, which were related to $\mathrm{Cs}_{2} \mathrm{O}$ content. Based on theory, ${ }^{19}$ if other factors are equal the material with the largest content of core particles and smallest size of core particles should be the strongest and toughest. However, this was not the case for the stabilized materials investigated by this laboratory. The materials, which had $\mathrm{Cs}_{2} \mathrm{O}$ added directly to the porcelain, ${ }^{1}$ had the largest leucite content (>60 wt.\%) and relatively small particle size $(<10$ $\mu \mathrm{m})$, but, as a group, had the lowest toughness of the synthesized leucite-based materials investigated by this laboratory.

The thermal expansion of the synthetic low leucite at 700 ${ }^{\circ} \mathrm{C}(1.74 \%)$ was greater than found for natural leucite $(1.62 \%)$, but the CTE was less than that of a synthetic leucite ${ }^{36}$ prepared by a coprecipitation process $\left(32 \times 10^{-6}\right.$ / $\left.{ }^{\circ} \mathrm{C}\right)$. There are no obvious explanations for these differences in the thermal expansion. There are considerable variations in the published values for CTE of high leucite (11.7-22.3 $\times$ $10^{-6 /{ }^{\circ}} \mathrm{C}$ ) ${ }^{26}$ The present values are within this range (Table I). It should be noted, however, that the high leucite used here had a significant composition difference from pure high leucite $\left(4 \mathrm{~mol} \% \mathrm{Cs}_{2} \mathrm{O}+12.7 \mathrm{~mol}_{2} \mathrm{~K}_{2} \mathrm{O}\right.$ vs. $\left.16.7 \mathrm{~mol} \% \mathrm{~K}_{2} \mathrm{O}\right)$, and had a small amount of low leucite [Figure 2(b)]. These two differences from pure high leucite may have affected the thermal expansion properties in some way.

The present data indicated that the stabilized high-leucite CTE was approximately the same as that for the synthesized low leucite up to around $400{ }^{\circ} \mathrm{C}$ (Table I and Figure 3). In contrast, it has been shown ${ }^{1}$ that when cesium was added in sufficient quantity $(2 \mathrm{~mol} \%)$ to a commercial porcelain to stabilize the cubic form of leucite at room temperature, the porcelain's CTE was significantly less than the unstabilized porcelain, even though the leucite content was determined to be the same. It is possible that the addition of cesium to the commercial porcelain significantly lowered the CTE of the glass phase of this porcelain. On this same subject, the CTE of sythetic pollucite was found ${ }^{37}$ to be considerably less than that of leucite, in contrast to the present findings. Pollucite has the same structure as cubic leucite, but with all $\mathrm{K}$ lattice sites replaced by $\mathrm{C}$. Considering the considerable difference in chemical content between the present cesium-stabilized cubic leucite and pollucite $\left(4 \mathrm{~mol} \% \mathrm{Cs}_{2} \mathrm{O}+12.7 \mathrm{~mol} \% \mathrm{~K}_{2} \mathrm{O}\right.$ vs. $16.7 \mathrm{~mol} \% \mathrm{Cs}_{2} \mathrm{O}$ ) differences in thermal expansion could be expected.

Another observation based on the curves shown in Figure 3 is related to determining the glass transition temperature $\left(T_{\mathrm{g}}\right)$ of the glass matrix from the thermal expansion curves for leucite porcelains. The basic shape of the thermal expansion curve for the NP porcelain is typical of many other commercial leucite porcelains. A comparison of the basic shape of the NP curve with that of the synthetic leucite curve shows that this basic shape could be explained by the presence of leucite in this material and by assuming that the matrix only diluted these effects. That is, the increase in slope that occurs from 350 to $450{ }^{\circ} \mathrm{C}$ and the decrease in slope that occurs from 600 to $650{ }^{\circ} \mathrm{C}$ for the MP matrix correspond to similar changes in the curve for the synthetic leucite material. These changes are probably associated with the transformation of low to high leucite and the thermal expansion of high leucite at high temperatures $\left(600-700{ }^{\circ} \mathrm{C}\right)$. Until a better understanding of the interaction between the glass matrix and the leucite core particles is obtained, the justification for making measurements of glass transition temperatures for leucite-glass porcelains made from their thermal expansion curves may not be based on a complete theoretical and experimental basis.

It is important to discuss how well the matrix materials met the design goals of homogeneity and matching of CTEs. Subjectively, an approximately 3:1 size difference between the added core particles and the low-leucite particles in the VP matrix materials does not appear sufficient to produce a uniform stress field around the added core particles, so that the matrix would appear as a homogeneous material. Additionally, the 3:1 ratio may have been altered by mixing the leucite and matrix together.

The NP material came much closer to matching the CTE of the $4 \mathrm{~mol} \% \mathrm{Cs}_{2} \mathrm{O}$ stabilized high leucite than did the VP material. How well this match was for the NP porcelain was dependent upon the glass transition temperature $\left(T_{\mathrm{g}}\right)$ of its glass phase. That is, potential thermally induced stresses above $T_{\mathrm{g}}$ would be reduced or eliminated by viscous flow within the liquid phase, whereas flow would not occur below the $T_{\mathrm{g}}$. The $T_{\mathrm{g}}$ would be, in turn, dependent upon how fast the specimens were cooled from the sintering temperature. The faster the cooling, the higher the $T_{\mathrm{g}}$ would have been. If the $T_{\mathrm{g}}$ of the $0.75 \mathrm{~mol} \% \mathrm{NP}$ specimens was in the range of $600-700{ }^{\circ} \mathrm{C}$, the stress field around the stabilized high leucite would have been neutral at $37{ }^{\circ} \mathrm{C}$ if the matrix behaved as a homogeneous material. However, a lower $T_{\mathrm{g}}$ would lead to a potential crack-deflecting stress field around the added core particles, reaching a maximum for this effect at a $T_{\mathrm{g}}$ of around $400{ }^{\circ} \mathrm{C}$.

As is evident in Figure 5, the 3:1 ratio was not achieved for the NP-based porcelains. Although the NP-matrix leucite 
particles were relatively fine (approximately $5 \mu \mathrm{m}$ or smaller) the added core particles were of similar size, as can be seen by comparing Figure 5(a) with Figure 5(b and c). Most likely, the matrix material did not act as a homogeneous material when the core particles were added to it. However, SEM fractographs (not shown here) showed that leucite particles were intersected and fractured for the $\mathrm{NP}(0.75)$ specimens, but not for the NP matrix material or the $\mathrm{NP}(0.0)$ material.

The authors gratefully acknowledge Professor Tseng-Ying Tien for suggesting that leucite porcelains may be susceptible to transformation toughening. They would also like to acknowledge the assistance of Kenneth Boenke.

\section{REFERENCES}

1. Rasmussen ST, Groh CL, O'Brien WJ. Stress induced phase transformation of a cesium stabilized leucite porcelain and associated properties. Dent Mater 1998; 14:202-211.

2. McLean JW. Current status and future of ceramics in dentistry. O'Brien WJ, Craig RG, editors. Proceedings of conference on recent developments in dental ceramics. Columbus, OH: American Ceramic Society; 1985. p 1-9.

3. Seghi RR, Denry IL, Rosenstiel SF. Relative fracture toughness and hardness of new dental ceramics. J Prosthet Dent 1995;74: $145-150$.

4. Wagner WC, Chu TM. Biaxial flexural strength and indentation fracture toughness of three new dental core ceramics. J Prosthet Dent 1996;76:140-144.

5. McLean JW. The future of dental porcelain. In: Preston JD, editor. Perspectives in dental ceramics. Proceedings of the Fourth International Symposium on Ceramics. Chicago: Quintessence; 1988. p 13-40.

6. Jones DW. The strength and strengthening mechanisms of dental ceramics. In: McLean, JW, editor. Dental ceramics. Proceedings of the First International Symposium on Ceramics. Chicago: Quintessence; 1983. p 83-141.

7. Jones DW. Development of dental ceramics: An historic perspective. Dent Clin N Am 1985;29:621-644.

8. O'Brien WJ. Recent developments in materials and processes for ceramic crowns. Am Dent Assoc J 1985;110:548-549.

9. Rouf MA, Hermansson L, Carlsson R. Crystallizations of glasses in the primary phase field of leucite in the $\mathrm{K}_{2} \mathrm{O}-\mathrm{Al}_{2} \mathrm{O}_{3}$ $\mathrm{SiO}_{2}$ system. Trans J Br Ceram Soc 1978;77:36-39.

10. Seghi RR, Daher T, Caputo A. Relative flexural strength of dental restorative ceramics. Dent Mater 1990;6:181-184.

11. Hahn C, Teuchert C. Importance of the glass ceramic system $\mathrm{K}_{2} \mathrm{O}-\mathrm{Al}_{2} \mathrm{O}_{3}-\mathrm{SiO}_{2}$ in dental porcelain. Ceram Forum Int 1980; 57:208-214.

12. Denry IL, Mackert JR Jr, Holloway JA. Effect of cubic leucite stabilization on the flexural strength of feldspathic dental porcelain. J Dent Res 1996;75:1928-1935.

13. Rasmussen ST, McLaren CI, O'Brien WJ. Stress induced transformation toughening of a dental porcelain. J Dent Res IADR Abstracts 1997;76:21.

14. Schairer JF, Bowen NL. The system $\mathrm{K}_{2} \mathrm{O}-\mathrm{Al}_{2} \mathrm{O}_{3}-\mathrm{SiO}_{2}$. Am J Sci 1955;253:681-746.

15. Peacor DR. A high temperature single crystal diffractometer study of leucite, (K,Na) $\mathrm{AlSi}_{2} \mathrm{O}_{6}$. Z Kristallogr Bd 1968;127: 213-224.
16. Fairhurst CW, Anusavice KJ, Hashinger DT, Ringle RD. Thermal expansion of dental alloys and porcelains. J Biomed Mater Res 1980;14:435-446.

17. Mackert JR Jr, Butts MB, Fairhurst CW. The effect of the leucite transformation on dental porcelain expansion. Dent Mater 1986;2:32-36.

18. Mackert JR Jr, Evans AL. Quantitative x-ray diffraction determination of leucite thermal instability in dental porcelain. J Am Ceram Soc 1991;74:450-453.

19. Hasselman DPH, Fulrath RM. Proposed fracture theory of a dispersion-strengthened glass matrix. J Am Ceram Soc 1966; 49:68-72.

20. McLean JW, Hughes TH. The reinforcement of dental porcelain with ceramic oxides. Br Dent J 1965; 119:261-267.

21. Morena R, Lockwood PE, Evans AL, Fairhurst CW. Toughening of dental porcelain by tetragonal $\mathrm{ZrO}_{2}$ additions. $\mathrm{J}$ Am Ceram Soc 1986;64:C74-C77.

22. Piché PW, O'Brien WJ, Groh CL, Boenke KM. Leucite content of selected dental porcelains. J Biomed Mater Res 1994;28: 603-609.

23. Kon M, Kawano F, Asaoka K, Matsumoto N. Effect of leucite crystals on the strength of glassy porcelain. Dent Mater J 1994;13:138-147.

24. Lee $\mathrm{HH}$, Kon M, Asaoka K. Influence of modification of $\mathrm{Na}_{2} \mathrm{O}$ in a glass matrix on the strength of leucite-containing porcelains. Dent Mater J 1997;16:134-143.

25. Lee HH, Kon M, Asaoka K. Mechanical properties of porcelain containing leucite ion-exchanged with rubidium. Dent Mater J 1998;17:93-103.

26. Mackert JR Jr, Butts MB, Morena R, Fairhurst CW. Phase changes in a leucite-containing dental porcelain frit. $\mathrm{J} \mathrm{Am}$ Ceram Soc 1986;69:C69-C72.

27. Morena R, Lockwood PE, Fairhurst CW. Fracture toughness of commercial dental porcelains. Dent Mater 1986;2:58-62.

28. Mackert JR Jr. Effects of thermally induced changes on porcelain-metal compatibility. In: Preston J, editor. Perspectives in dental ceramics. Proceedings of the Fourth International Symposium on Ceramics. Chicago: Quintessence; 1988. p 53-64.

29. Mackert JR Jr, Williams AL. Microcracks in dental porcelain and their behavior during multiple firing. J Dent Res 1996;75: 1484-1490.

30. Lang FF. Transformation toughening, Part 2. Contribution to fracture toughness. J Mater Sci 1982;17:235-239.

31. McLean JW. The future for dental porcelain. McLean JW, editor. Dental Ceramics. Proceedings of the First International Symposium on Ceramics. Chicago: Quintessence; 1983. p 1340.

32. Cullity BD. Elements of x-ray diffraction. Reading, MA: Addison-Wesley; 1978. p 407-420.

33. Anstis GR, Chantikul P, Lawn BR, Marshall DB. A critical evaluation of indentation techniques for measuring fracture toughness: I. Direct crack measurements. J Am Ceram Soc 1981;64:533-538.

34. Seghi RR, Denry I, Brajevic F. Effects of ion exchange on hardness and fracture toughness of dental ceramics. Int J Prosthodont 1992;5:309-314.

35. O'Brien WJ. Dental materials and their selection. Chicago: Quintessence; 1997. p 331-404.

36. Yoon CK, Rasmussen ST, O'Brien WJ, Tien TY. Properties of leucite-glass composites prepared by a coprecipitation process. J Mater Res 1994;9:2285-2289.

37. Taylor D, Henderson CMB. The thermal expansion of the leucite group of minerals. Am Mineral 1968;53:1476-1489. 